\title{
FENESTRATE BRYOZOANS IN THE ACANTHOPYGE LIMESTONE (EIFELIAN) IN THE BARRANDIAN AREA (CZECH REPUBLIC)
}

\section{Michal Mergl}

Centrum biologie, geověd a envigogiky, Fakulta pedagogická, Západočeská univerzita v Plzni, Klatovská 51, 30619, Plzeň

\begin{abstract}
The first occurrence of fenestrate bryozoans is reported from the Acanthopyge Limestone (Eifelian) in the Koněprusy area of the Czech Republic. Fragmented zoaria have been identified in lightgrey crinoidal-limestone rich with brachiopods, corals, and stromatoporoids. Several species of fenestrates are evident, but poor preservation and fragmentation of zoaria allow only approximate taxonomic determination. The fenestrates, Fenestella sp., Laxifenestella (?) sp., Hemitrypa sp., Polyporella sp., Ptylopora sp., and Reteporina sp., are illustrated and briefly described. The presence of fenestrates has a great palaeoenvironmental significance. Fenestrates together with brachiopods, stromatopoids, and corals indicate a high-energy reef environment on the Konéprusy submarine elevation in the upper Eifelian. Morphology of fenestrates and high morphological disparity of brachiopods are remarkably similar to the faunas of the Pragian age in the Koněprusy area suggesting a similar reef environment. The upper Eifelian age of the locality is evidenced by conodonts of the Tortodus kockelianus Zone.
\end{abstract}

Key words: fenestrata, bryozoa, Acanthopyge Limestone, Eifelian, Koněprusy, Devonian, Barrandian

\section{INTRODUCTION}

Fenestrate bryozoans (Bryozoa, Stenolaemata, Fenestrata) are not common in the Barrandian area. There are two exceptions; in the white reef Koněprusy limestone (Pragian) in the Koněprusy area fenestrates are remarkably diverse and abundant and in some biodetritic limestone beds in the lower part of the Zlíchov Limestones (Zlíchov Formation, Lower Emsian) fenestrates are also abundant. Some fenestrate species from these stratigraphic units of the Barrandian area were described already at the end of the 19th (Počta, 1894) and in the early 20th Century (Prantl, 1932). McKinney \& Kř́ž (1986) named new and revised all species from the Koněprusy and Zlíchov limestones. Morozova (2001) and Suárez-Andrés and McKinney (2010) also discuss the fenestrates from these two limestones. In the Barrandian area the fenestrates were also reported in the Motol Formation (Wenlock) by Počta (1894) but these were not revised (Prantl, 1932). The presence of fenestrates in the Kopanina Formation (Ludlow) and the Acanthopyge Limestone are noted, without discussion by Hladil et al. (1992) and Hladil (1993).

Recent sampling in the white to grey crinoidal limestone of the Acanthopyge Limestone (Eifelian) have yielded, apart of brachiopods and corals, a small collection of the fenestrate bryozoans. Limestone beds outcrop in an abandoned small quarry at the Zadní Kobyla ridge. Despite the high fragmentation and poor preservation, these Eifelian fenestrates are briefly described and illustrated herein, because their presence indicates previously unknown benthic association of a high-energy environment.

\section{LOCALITY: GEOGRAPHIC AND GEOLOGIC SETTING}

Fenestrate bryozoans were sampled in white to light grey crinoidal Acanthopyge Limestone on the Zadní Kobyla ridge near Koněprusy. The stratigraphic position of the fossiliferous bed was described by Mergl (2014). Crinoidal limestone outcrops at north side of a small shallow abandoned quarry. Fauna, found in a $30 \mathrm{~cm}$ thick limestone bed, is remarkably rich in corals, crinoids and brachiopods. Other faunal elements, trilobites, gastropods, and bivalves are rare. An upper Eifelian age for the limestone is based on the presence of conodonts of the Tortodus kockelianus Zone (determined by S. Vodrážková, pers. comm. 2015). 


\section{MATERIAL AND TERMINOLOGY}

Fenestrates are rare in the Acanthopyge Limestone. Zoaria are strongly fragmented, with fragments size rarely exceeding $10 \mathrm{~mm}$. The overall shapes of zoaria are unknown, but in some cases basal parts indicate the shape of the zoarium. Reverse surface of zoaria are always faced on a surface of splitted rock.

Several morphotypes were identified among the fragments. Three are represented by only one specimen. Lack of more complete specimens and poor preservation did not allowed use standard methods for more precise determinations. Tangential sectioning and acetate peels (see McKinney \& Kř́iž, 1986) were used to study of only the commonest morphotypes. The terminology used herein is after McKinney \& Křríž (1986).

All specimens, including unfigured fragments and acetate peels are stored in the palaeontological collections of the University of West Bohemia at Plzeň (PCZCU 2002-2035).

\section{SYSTEMATICS}

Class Stenolaemata Borg, 1926

Order Fenestrata Elias \& Condra, 1957

Family Fenestellidae King, 1849

Fenestella Lonsdale, 1839

Type species: Fenestella subantiqua d'Orbigny, 1852

Fenestella sp. (Plate II, figs 1-3)

Material: Four fragments (PCZCU 2006, 2016, 2019, 2024), the largest $9 \times 10 \mathrm{~mm}$, all with reverse surface exposed; acetate peel from PCZCU 2024.

Description: Zoarium probably funnel shaped. Branches are straight, $0.20-0.25 \mathrm{~mm}$ wide, perfectly parallel, connected by regularly spaced dissepiments about $0.95 \mathrm{~mm}$ apart. Fenestrules are uniformly sized, oval to elongate, subhexagonal in outline, with a perfect honeycomb alignment. Autozooecia alternate in position along branches.
The axial wall is zig-zag shaped. Zooecial chambers are five-sided, with a short cylinder of lesser diameter and distal lobes with circular aperture gently inclined out from a low keel.

Remarks: Among the fenestrates at the Zadní Kobyla, the species is distinguished by a perfectly parallel narrow branches, uniformly sized fenestrules, and aperture of autozooecia adjacent to a keel. Species Fenestella gracilis (Barrande, 1894) differs by straight axial wall, and much elongate autozooecia. The absence of nodes or spines on the Fenestella sp. distinguishes this morphotype from other species of Fenestella known in the Koněprusy limestone.

Occurrence: Eifelian, Acanthopyge Limestone; Barrandian, Koněprusy, Zadní Kobyla.

\section{Laxifenestella Morozova, 1974}

Type species: Fenestella sarytschevae Schulga-Nesterenko, 1951

Laxifenestella (?) sp. (Plate I, figs 5-10)

Material: Eight fragments (PCZCU 2013, 2017, 2018, 2025, 2026, 2028, 2031, 2032), with the largest $10 \times 11 \mathrm{~mm}$, all with reverse surface exposed; acetate peels from PCZCU 2017 and PCZCU 2018. Description: Zoaria are either fan-shaped or broadly conical. Branches are straight to sinuous, often bifurcate, connected by distinctly thinner and irregular dissepiments. Fenestrules are triangular to hexagonal, remarkably variable in size and outline in the distal part of zoarium. In the proximal part of the zoarium they are much more circular and smaller. Spacing between branches is 0.80 $1.50 \mathrm{~mm}$. Spacing between adjacent dissepiments is variable, usually $1.20-1.90 \mathrm{~mm}$ apart, but may be less than $0.40 \mathrm{~mm}$. Spacing between branches, dissepiments and irregularity gradually increase with an increase in size of a zoarium.

Autozooecia alternate in position along branches. The axial wall is gently zig-zag shaped. Zooecial chambers are subhexagonal to kidney-shaped, with short cylinder extending distally at about $45^{\circ}$ to the frontal surface. Distal tubes are short, gently inclined toward the adjacent fenestrules. Keel rather high, without nodes and spines.

Plate I. 1, 2 - Polypora sp., fragment of zoarium, PCZCU 2003. 3 - Ptylopora sp., fragment of zoarium, PCZCU 2002. 4 - Hemitrypa sp., fragment of zoarium, PCZCU 2004. 5-10 - Laxifenestella (?) sp., diverse fragments of zoaria, and acetate peels of tangential section, PCZCU 2018, PCZCU 2013, PCZCU 2028, PCZCU 2028, PCZCU 2026, PCZCU 2031, Eifelian, Acanthopyge Limestone, Zadní Kobyla locality, Koněprusy area, Central Bohemia. Bar = $1 \mathrm{~mm}(1-6,9,10)$ and 0.1 mm $(7,8)$. 
Plate I.
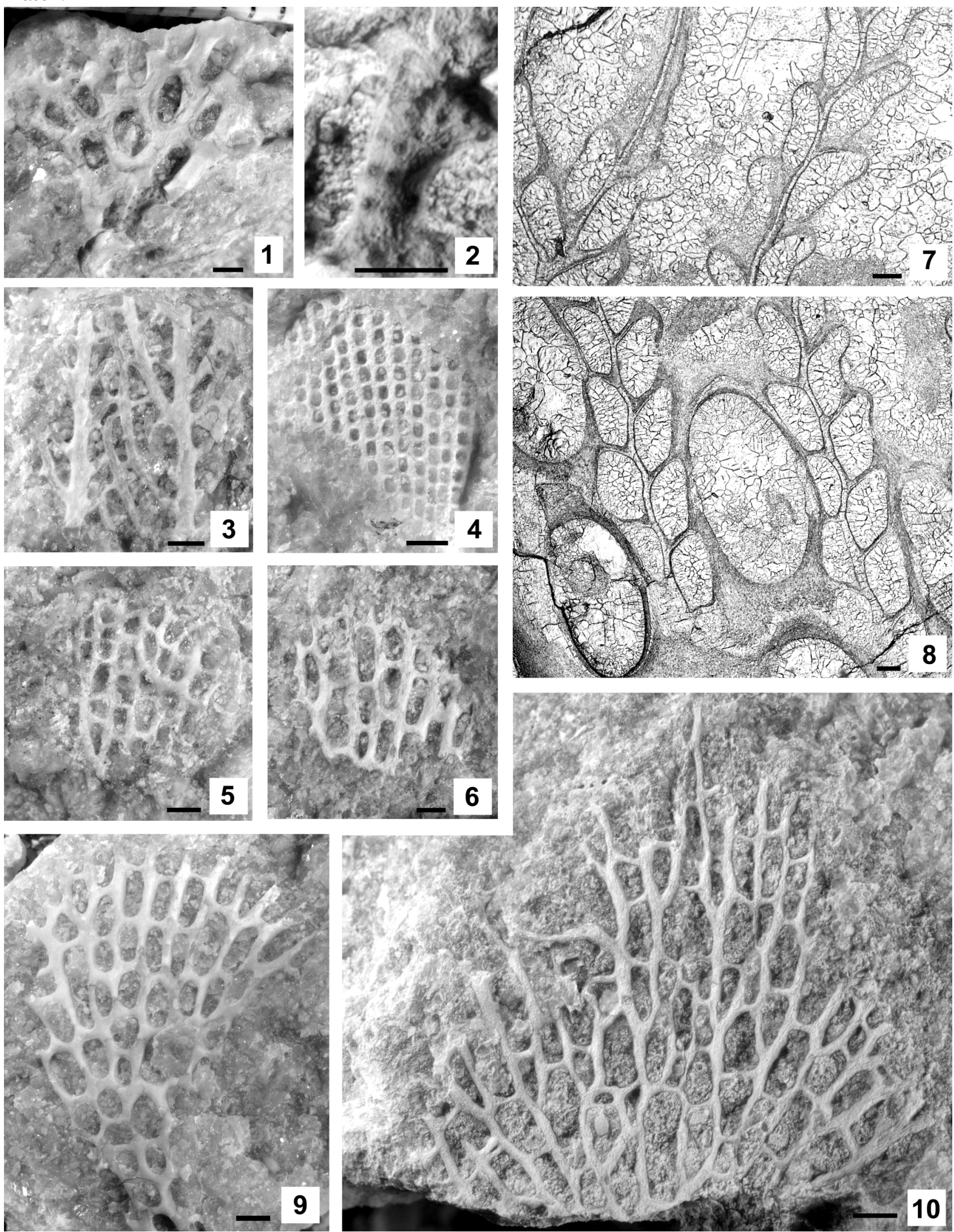
Remarks: The specimens are referred to Laxifenestella although the keel is without nodes. However, other features are similar to L. capillosa (Počta, 1894) and L. digittata (Prantl, 1932). The characteristic feature of Laxifenestella (?) sp. is the variability in shape of fenestrules and branches.

Occurrence: Eifelian, Acanthopyge Limestone; Barrandian, Koněprusy, Zadní Kobyla.

Hemitrypa Phillips, 1841

Type species: Hemitrypa oculata Phillips, 1841

Hemitrypa sp. (Plate I, fig. 4)

Material: One fragment $\approx 6 \times 5 \mathrm{~mm}$ sized (PCZCU 2004), with reverse surface exposed.

Description: Zoarium is likely funel-shaped, with an undulatory surface because the superstructure of the fragment has a concave surface. The specimen has straight branches about $0.20 \mathrm{~mm}$ wide, spaced $0.35-0.40 \mathrm{~mm}$ apart, connected by regularly spaced dissepiments $0.45-0.55$ apart. Its superstructure has $0.15 \mathrm{~mm}$ openings. Details of zooecia are unknown.

Remarks: Because of rarity and minute size of the specimen no acetate peel was prepared. They general shape, and size of the straight branches of $H$. sp. suggest it is similar to $H$. tenella Barrande, 1894.

Occurrence: Eifelian, Acanthopyge Limestone; Barrandian, Koněprusy, Zadní Kobyla.

Polyporella Simpson, 1895

Type species: Fenestella fistulata Hall, 1884

Polyporella sp. (Plate I, figs 1, 2)

Material: One subrectangular fragment $\approx 7 \times 8 \mathrm{~mm}$ (PCZCU 2003), with reverse surface exposed.

Description: Sinuous branches about $0.60 \mathrm{~mm}$ wide, spaced $1.60-1.70 \mathrm{~mm}$ center to center, connected by variably spaced narrower dissepiments. Branches bear from three or four rows of zooecia. Remarks: The fragment displays three apertures on a branch (Pl. I, figs 1, 2), but because no peel was prepared the details of zooecia are unknown. The fragment differs from other sampled fenestrate fragments in the Acanthopyge Limestone by robust branches and more than two rows of zooecia. Similar width and spacing of branches has $P$. inusitata McKinney \& Kř́iž, 1986 from the Zlíchov Formation (Lower Emsian), from which $P$. sp. likely differs by lesser number of rows of zooecia.

Occurrence: Eifelian, Acanthopyge Limestone; Barrandian, Koněprusy, Zadní Kobyla.

\section{Ptylopora M'Coy, 1844}

Type species: Ptylopora pluma M'Coy, 1844

Ptylopora sp. (Pl. 1, fig. 3)

Material: One subrectangular fragment $\approx 6 \times 7 \mathrm{~mm}$ sized (PCZCU 2002), with reverse surface exposed. Description: The fragment exhibits two linear subparallel lateral branches of the first order and slightly sinuous thinner lateral branches of the second order. The first order lateral branches are robust, $0.35-0.55$ wide, branching at low angle into thinner, more irregular secondary branches $0.15-0.25 \mathrm{~mm}$ wide. Branches are connected by narrower irregular dissepiments $0.15 \mathrm{~mm}$ wide. There are two rows of zooecia present on lateral branches, but other details of zooecia are unknown.

Remarks: Single observed fragment indicates presence of Ptylopora in the Eifelian of the Barrandian. Similar species Ptylopora bohemica Prantl, 1928 is rare in the Koněprusy Limestone (Pragian) of the Barrandian. Widths of the lateral branches of Ptylopora sp. fall within the range of P. bohemica (see McKinney \& Kř́žz, 1986; tab. 7). The shape of complete zoarium is unknown.

Occurrence: Eifelian, Acanthopyge Limestone; Barrandian, Koněprusy, Zadní Kobyla.

Family Semicosciniidae Morozova, 1987

Reteporina d'Orbigny, 1849

Type species: Retepora prisca Goldfuss, 1849

Reteporina sp. (Plate II, figs 4-9)

Material: 18 fragments (PCZCU 2005, 2007, 20092012, 2014, 2015, 2020-2023, 2027, 2029, 2030, 2033-2035), with the largest $10 \times 12 \mathrm{~mm}$ fragment,

Plate II. 1-3 Fenestella sp., two fragments of zoaria and acetate peel of tangential section, PCZCU 2019, PCZCU 2006, PCZCU 2024. 4-9 Reteporina sp., three fragments of zoaria (4, 5, 9), proximal funnel-shaped part of zoarium (6), and acetate peels of tangential section (7, 8) PCZCU 2015, PCZCU 2011, PCZCU 2035, PCZCU 2005, PCZCU 2005 , PCZCU 2017. Eifelian, Acanthopyge Limestone, Zadní Kobyla locality, Koněprusy area, Central Bohemia. Bar = 1 mm (1, 2, 4-6, 9) and $0.1 \mathrm{~mm}(3,7,8)$. 


\section{Plate II.}

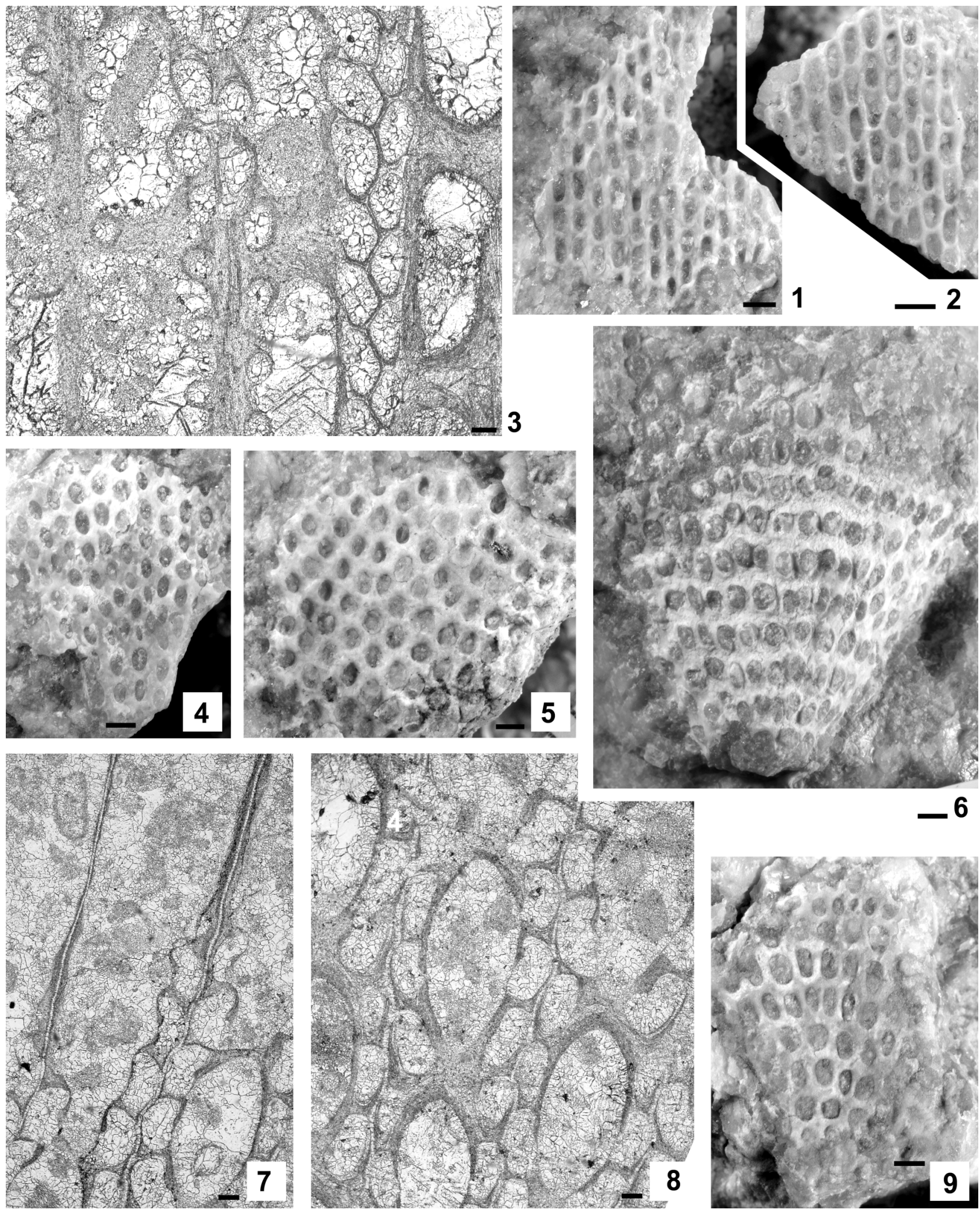


all with reverse surface exposed; acetate peels of PCZCU 2005 and PCZCU 2035.

Description: Zoarium probably funnel shaped, with narrow proximal part. Branches are weakly sinuous to anastomosing, regularly connected, 0.30-0.35 $\mathrm{mm}$ broad, spaced $0.75 \mathrm{~mm}$ center to center. Fenestrules are uniformly sized, subcircular to gently elliptical, $0.75-0.85 \mathrm{~mm}$ long and $0.35-0.40 \mathrm{~mm}$ wide, with slightly irregular honeycomb alignment. Autozooecia alternate in position along branches. The axial wall is gently zigzag shaped. Zooecial chambers are kidney shaped, with a short cylinder of lesser diameter gently inclined out from branch. Keel is distinct, high, with thickened lamellar skeleton, without nodes or spines. Remarks: Reteporina sp. is similar to $R$. petala (Počta, 1894) from the Koněprusy Limestone (Pragian) by anastomosed branches, size and shape of fenestrules and by narrowly funnelshaped proximal part of the zoaria.

Occurrence: Eifelian, Acanthopyge Limestone; Barrandian, Koněprusy, Zadní Kobyla.

\section{CONCLUSION}

Occurrence of six different species of fenestrate bryozoans in the Acanthopyge Limestone indicates a high-energy reef environment and a moderate diversity of fenestrate bryozoan in the reef in the upper Eifelian. The reef environment in the Koněprusy area was established for the first time in the Pragian (Svoboda \& Prantl, 1949; Chlupáč, 1957). The reef had a high diversity of marine biota, and fenestrate bryozoans were, apart from the associated crinoids, corals and rhynchonelliform brachiopods, the major component of the reef (McKinney \& Kř́ž́, 1986). After the emergence of the reef and a stratigraphic break in the Lower Emsian, a moderately deep environment was established in the Upper Emsian (the Suchomasty Limestone and the lower part of the Acanthopyge Limestone). This moderately deep environment with diverse crinoids, proetid trilobites (Šnajdr, 1980) and small smooth-shelled spire-bearing brachiopods (Havlíček \& Kukal, 1990) lacks fenestrate bryozoans. A shallower high-energy reef environment reappeared in the upper Eifelian. This is evident from abundant and often worn rugose and tabulate corals, stromatoporoids and diverse, predominantly costate or costellate medium-sided rhynchonelliform brachiopods (atrypids, strophomenids, rhyn- chonellids, orthids, spiriferids). This environment allowed the fenestrate bryozoans to proliferate once again but for the last time in the Koněprusy area. The composition of the Eifelian association is remarkably similar to the composition of fenestrate association of the Pragian age. However, diversity of the Eifelian-aged fenestrates is lower than the Pragian-aged fenestrates. In the Koněprusy Limestone (Pragian) the fenestrates are represented also by species that belong to Utropora, Cyclopelta, Semicoscinium, Isotrypa, Penniretepora, and Filites. These genera are yet unknown in the Acanthopyge Limestone. Subsequent deepening, indicated by a dark limestone interval (Kačák Event; Hladil et al., 1992; Hladil, 1993; Budil, 1995), and onset of clastic sedimentation of the Srbsko Formation was no longer conducive to reef development in the Koněprusy area.

\section{ACKNOWLEDGEMENTS}

Author is greatly indebted to Stanislava Vodrážková for determination of the conodonts. This study was supported by a grant of the Grant Agency of the Czech Republic GAČR No. P210-12-2018.

\section{REFERENCES}

Budil, P. 1995. Demonstration of the Kačák event (Middle Devonian, uppermost Eifelian) at some Barrandian localities. Věstník Českého geologického ústavu 70(4), 1-24.

Chlupáč, I. 1957. Facial development and biostratigraphy of the Lower Devonian of Central Bohemia. Sborník Ústředního ústavu geologického, oddíl geologický 23, 369-485.

Havlíček, V. \& Kukal, Z. 1990. Sedimentology, benthic communities, and brachiopods in the Suchomasty (Dalejan) and Acanthopyge (Eifelian) Limestones of the Koněprusy area (Czechoslovakia). Sborník geologických věd, Paleontologie 31, 105-205.

Hladil, J. 1993. Tabulatomorphs and stromatoporoids below and above the upper boundary of the Acanthopyge Limestone (Eifelian/Givetian transition interval, Central Bohemia). Věstník Českého geologického ústavu 68(2), 27-42.

Hladil, J., Beroušek, P. \& Lukeš, P. 1992. Temné vápencové vrstvy při stropu akantopygových vápenců u Koněprus - otomari-Kačák event. Zprávy o geologických výzkumech v roce 1991, 53-55. 
McKinney, F.K. \& Kříž, J. 1986. Lower Devonian Fenestrata (Bryozoa) of the Prague Basin, Barrandian Area, Bohemia, Czechoslovakia. Fieldiana, Geology, new series 15, 1-90.

Mergl, M. The first occurence of the Devonian rugose coral Calceola sandalina (Linné, 1771) in the Barrandian area, Czech Republic. Folia Musei Rerum Naturalium Bohemiae Occidentalis, Geologica et Paleobiologica, 48 (1-2), 11-19.

Morozova, I. P. 2001. Bryozoa. Order Fenestellida (morphology, systematics, and history of development). Rossiyskaya Akademiya Nauk. Trudy paleontologitscheskogo Instituta, 277. Moskva. $112 \mathrm{pp}$.

Počta, P. 1894. Systeme Silurien du Centre de la Boheme par Joachim Barrande. Iere Partie: Recherches Paleontologiques, Vol. VIII. Tom Ier. Bryozoaires, Hydrozoares et partie des Anthozoaires. $230 \mathrm{pp}$.
Prantl, F. 1928. Příspěvek k poznání mechovek $\mathrm{z}$ vápenců koněpruských. Rozpravy II. tř́ldy České Akademie 27, 10, 1-3.

Prantl, F. 1932. Revise českých devonských fenestellid. Palaeontographica Bohemiae 15, 1-70.

Suárez-Andrés, J. L. \& McKinney, F. K. 2010. Revision of the Devonian fenestrate bryozoan genera Cyclopelta Bornemann, 1884 and Pseudoisotrypa Prantl, 1932, with description of a rare fenestrate growth habit. Revista Española de Paleontología 25(2), 123-138.

Svoboda, J. \& Prantl, F. 1949. Stratigraficko-tektonická studie o devonské oblasti koněpruské. Sborník Státního geologického ústavu Československé republiky 16, 5-92.

Šnajdr, M. 1980. Bohemian Silurian and Devonian Proetidae (Trilobita). Rozpravy Ústředního ústavu geologického 45, 1-324. 